\section{SOLICITORS' CONFLICTS OF INTEREST}

The phrase "conflicts of interest" has become a fashionable portmanteau expression to describe a variety of legal circumstances. It is not always appropriate. In the US it has been used as a euphemism to describe the alleged practice in some investment banks of analysts lying to the banks' clients about their own views, in order to induce the clients to buy shares, and thereby to secure fees for the bank from the company whose affairs were misrepresented. It may only be a matter of time before a burglar excuses his conduct as arising from a "conflict of interest" between his duty to respect the householder's rights of private property and his own wish to appropriate that property.

There is, however, one area in which the phrase correctly identifies a serious and growing problem. As firms of solicitors have grown larger and/or have merged with each other, an increasing number of situations have arisen where a firm has been asked to act in a dispute with a former client, or to represent several parties in the same commercial or financial transaction. This has given rise to the claim, particularly by larger commercial practices, that existing practice rules are obsolete or unclear. The Law Society must formulate new rules, it is said, to accommodate modern practice.

There are, indeed, issues that need to be addressed and rules of law that should be reassessed. But the problems and the solutions are not necessarily those that have been identified by the participants in the public debate. On one hand it is claimed that the large firms "ignore the rules on conflicts". On the other, large firms claim that "the conflicts rules are unclear and difficult to follow". Neither statement is correct. As every law student is taught (although the lesson is usually forgotten on the date of qualification) the first step in dealing with any legal problem is to be clear about the identity of the problem. In the case of legal professional conflicts, there are on examination two issues which are discrete and clear. The outline of each, however, is obscured by the presence of the other.

First, the relationship of solicitor and client gives rise to fiduciary duties of loyalty and care. The scope and nature of those duties have been, and continue to be, described by case law and are refined and changed in line with the view of the courts of the social context in which the legal rules operate. That context may well be influenced by the practice of professionals and by guidance issued by The Law Society. However, neither The Law Society nor any other body can change the legal obligations of the solicitor fiduciary without statutory authority.

The other issue springs from the fact that, even after the solicitor/client relationship is ended, the fiduciary continues to owe a duty of confidence to his former client.

Articles
"Lecky's circle": thoughts from the frontier of
international law I
$\begin{aligned} & \text { A comparison of the risks between the use of } \\ & \text { manuscript and electronic signatures }\end{aligned}$
$\begin{aligned} & \text { Society and Institute News } \\ & \text { Articles (cont'd) }\end{aligned}$
$\begin{aligned} & \text { Challenging an arbitration award: some key } \\ & \text { principles } \\ & \text { Settlement of disputes under the Financial } \\ & \text { Services and Markets Act II }\end{aligned}$

Thus, he may be prevented from acting contrary to the interests of his former client, if he might use or disclose confidential information in the course of his new instructions (see Prince Jafri Bolkiah v KPMG [1999] 2 AC 222 for a full discussion). Again, the existence of the duty is a matter of general law. The steps necessary to comply with the solicitor's obligations are to be found in case law, rather than in Law Society guidance.

So far as statute is concerned, the relevant provision is clear:

"A solicitor shall not do anything ... which compromises or impairs or is likely to compromise or impair ... the solicitor's duty to act in the best interests of the client"

(Solicitors' Practice Rules 1990, r 1).

The underlying duty (to act in the best interests of the client) is imposed and defined by case law. The Law Society can, and does, provide helpful guidance on how solicitors might ensure that they comply with their duties. It cannot, however, directly change the contents of those duties, nor grant exemptions from them.

The area is ripe for review and, perhaps, reform. But the review needs to take place as part of the normal process of law reform. There is nothing to be gained by haranguing or browbeating the Law Society.

\section{Colin Bamford}

Barrister, 3/4 South Square

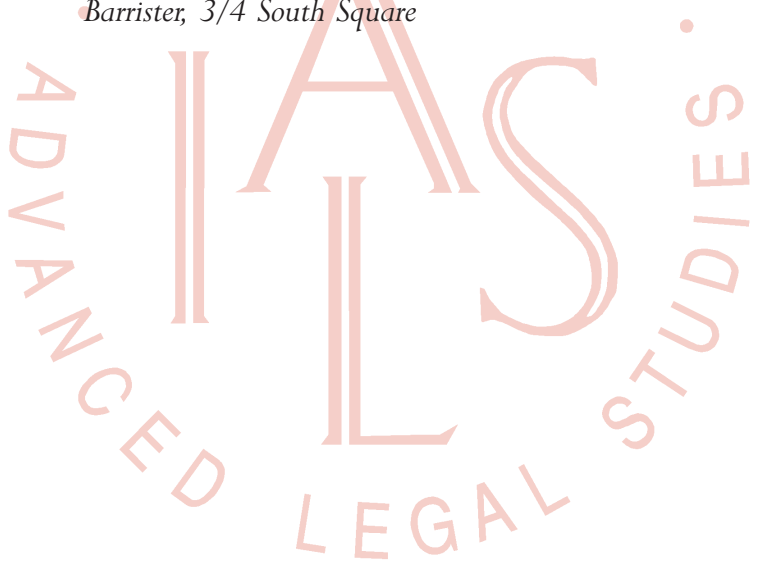

